\title{
Effect of Incorporation of Drumstick Leaf Powder and Defatted Soybean Flour on Texture, Colour and Organoleptic Evaluation of Instant Noodles
}

\author{
Vittal Kamble $^{1 *}$, G. Bhuvaneshwari ${ }^{1}$, Vasant M. Ganiger ${ }^{2}$, \\ Deepa Terdal $^{1}$ and Y.K. Kotikal ${ }^{3}$ \\ ${ }^{1}$ Department of Post-Harvest Technology, ${ }^{2}$ Department of Vegetable Science, \\ ${ }^{3}$ Department of Entomology, College of Horticulture Bagalkot, Karnataka-587104, India \\ *Corresponding author
}

\section{A B S T R A C T}

\section{Keywords}

Instant noodles, Refined wheat flour, Drumstick leaf powder, Defatted soybean flour

\section{Article Info}

Accepted:

28 January 2018

Available Online:

10 February 2018
Refined wheat flour (RWF) was blended with drumstick leaf powder (DLP) and defatted soybean flour (DSF) to prepare instant noodles. Prepared instant noodles were evaluated for texture of raw and cooked noodles, $L^{*}$ $a^{*} b^{*}$ values and organoleptic parameters. Texture profile analysis of raw and cooked noodles indicated that hardness values significantly increased as the incorporation of DLP decreases. $L^{*} a^{*} b^{*}$ values were decreased as the incorporation of DLP increases and acceptable instant noodles were prepared by 5 per cent incorporation of DLP into the instant noodles. These results suggest that reduction of incorporation of DLP could provide beneficial effect on the quality improvement of instant noodles.

\section{Introduction}

Moringa oleifera commonly called Moringa is a valuable tree whose fruits, roots and leaves have been advocated for traditional, medicinal and industrial uses. The phytochemical and nutritional properties of the dried leaf powder of $M$. oleifera used as nutraceuticals, dietary supplements, functional foods or a source of vegetable in meal preparation. Drumstick leaf powder is a rich source of tannins, saponins, alkaloids, flavonoids, cardiac glycosides and reducing sugars and also proteins $(24.31 \%)$, carbohydrate $(55.97 \%)$, ashes $(11.50 \%)$, crude fiber $(10.28 \%)$, total fat $(9.22 \%)$, moisture $(6.12 \%)$, caloric value $(404.10 \mathrm{Kcal}$ $/ 100 \mathrm{~g})$ and saturated fatty acids (3.77 \%), unsaturated fatty acids (5.45 \%), monounsaturated fatty acids $(0.87 \%)$, polyunsaturated fatty acids $(4.58 \%)$ and Trans fatty acid $(0.00 \%)$ for fatty acid profile Isitua et al., (2015).

Wheat flour and defatted soybean flour are widely used in the food industry (Vetter, 1988) these are rich source of dietary fibres and proteins. There is a new tendency to add vegetable materials to the basic ingredients of wheat flour (Collins and Pangloli (1997); Senthil, Ravi, Bhat and Seethalakshmi (2002); Skrbic, Milovac, Dodig, and Filipcev (2009); 
Wang, Rosell, and Benedito de Barber (2002). Such added ingredients can provide different flavours, colours, additional nutrients and often health benefits. Physicochemical properties of basic ingredients will be changed, in part, by the addition of these materials. Noodles that are prepared with drumstick leaf powder and defatted soybean flour can increase the $\beta$ - carotene and protein content as well as increase the cooking loss of noodles (Collins and Pangloli (1997)).

Noodles are traditional food in China and other Asian countries, and have been flavoured by the Chinese people for over 2000 years. Noodles constitute almost $40 \%$ of wheat products in Asia (Janto et al., (1998); $\mathrm{Hu}$ et al., (2006). The quality of wheat noodles and instant noodles depends mainly on their physical, chemical and microbiological stability (Menkov et al., 2005). Among ready to eat foods, noodles form an important part of Indian dietary. It is rich in starch and energy but depleted in fibre and other nutrients. So, value addition to noodles can help to improve its physicochemical and sensory characteristics. Therefore, value addition of instant noodles is of prime importance to improve nutrient content and to save its delicacy. Secondly, use of value added processed foods could be a solution to the problem of supplementary feeding in under nutrition (Gernah et al., 2011). The objective of this study was to investigate the texture, colour and sensory properties of instant noodles incorporated with drumstick leaf powder and defatted soybean flour.

\section{Materials and Methods}

Fresh drumstick leaves were procured from the trees of drumstick variety KDM-01 (Bhagya) plantation maintained by Main Horticulture Research and Extension Centre, UHS, Bagalkot at Sector No.1. These leaves were made into a powder after drying under electrical tray drier at $60^{\circ} \mathrm{C}$ temperature.
Dried drumstick leaf powder was packed separately in LDPE bags (200gauze) for further use.Defatted soybean flour was procured from Ahmed shopping centre, Bengaluru. Starch and guar gum was purchased from Aminghad Agencies, Dharwad. Masala ingredients, salt and vegetable oil were procured from local market Vidyagiri, Bagalkot. Hydrolysed ground nut cake was purchased from Kenchannawar oil mill, Bagalkot.

Preparation of noodles incorporated with drumstick leaf powder and defatted soybean flour

All the ingredients such as refined wheat flour, drumstick leaf powder, defatted soybean flour, salt, starch, citric acid, potassium carbonate, sodium carbonate, vegetable oil and gum were weighed as shown in Table 1. The composite flour was mixed with water and kneaded for 10 minutes and kept the dough aside for $30 \mathrm{~min}$. The dough was passed through a dough roller to make in to sheet. These sheets overlapped one on the other and passed through a vertical noodles making machine mechanically to make cuts and longer types of noodles. The prepared raw noodles were then steamed at $100^{\circ} \mathrm{C}$ for 15 minutes in a pressure cooker. The noodles were then dried in a tray dryer at $80^{\circ} \mathrm{C}$ for 2 hours. The cooled and dried instant noodles were packed in polythene bags (50 micron). Each replication in a treatment has $250 \mathrm{~g}$ instant noodles.

Texture of raw and cooked noodles (Newton)

Texture measurements in this study were obtained using TA-XT-plus Texture Analyser (Stable Micro Systems, London, England) as used by Park and Baik (2004), Cato, Halmos and Small (2006). The instrument was first calibrated using $10 \mathrm{~kg}$ load cell and the return trigger path was $15 \mathrm{~mm}$. The settings were as 
follows; mode setting was on measure force in compression; pre-test speed, test speed and post-test speed were all set to $2.0 \mathrm{~mm} / \mathrm{sec}$; strain was on $75 \%$; trigger type was set on auto $10 \mathrm{~g}$; and either $35 \mathrm{~mm}$ (Stable Micro Systems, 2000) or $45 \mathrm{~mm}$ of cylinder probe were used for different tests purposes. The noodle strands were arranged completely flat and as closely as possible to each other. Three measurements were taken for both raw and cooked noodles. The results were presented as noodle hardness in Newton $(\mathrm{N})$ which was obtained from the peak of the graph.

$L * a * b *$ values

Noodles colour was measured with a Color Flex EZ (mode CFEZ 1919, Hunter associates laboratory, Inc., Reston) with a $45 \mathrm{~mm}$ (diameter) measuring tube using a white tile background. $L^{*}, a^{*}$ and $b^{*}$ values denote lightness (white-black), red-green and yellowblue scales, respectively. Three colour readings per noodle sample were made. Measurements were made three times, each at a different location on the consistent (same) side of the surface of the noodles. There were three replicate noodle samples for each treatment.

\section{Sensory evaluation ( 9 point hedonic scale)}

Noodles of different treatments (Table 1) were prepared as per the procedure given in Figure 1. Samples (30g) from each treatment were cooked for 2 minutes by adding masala taste maker $(0.35 \mathrm{~g})$, kept in hot boxes and used for sensory evaluation.

Sensory evaluation of noodles incorporated with drumstick leaf powder and defatted soybean flour was carried out by a panel of semi-trained judges consisting of Teachers and Post-Graduate students of College of Horticulture, Bagalkot. The sensory characters like colour and appearance, flavour, taste, mouth feel (texture) and overall acceptability were evaluated on a 9 point
Hedonic scale using the score card.

\section{Statistical analysis}

All measurements were performed in triplicate. Statistical analyses were carried out with the software wasp (ICAR Research Complex Goa) using one-way analyses of variance (ANOVA). $\mathrm{P}<0.01$ was considered to be significant.

\section{Results and Discussion}

\section{Preliminary evaluation}

The level of ingredients and formulation of the layered dough was based on the preliminary work (Table 1). For instance the reason for using $10 \mathrm{~g} / 100 \mathrm{~g}$ of DSF in all the treatment was to check the cooking properties of instant noodles at same level of incorporation.

\section{Texture of raw and cooked noodles} (Newton)

Initially, the use TA-XT-plus Texture Analyser with different sizes of the cylinder probe and sampling arrangement on this apparatus were studied. Finally $45 \mathrm{~mm}$ of cylinder probe was found to be suitable and it was used for different tests (Fig. 2).

In raw noodles the mean texture ranged between $17.92 \mathrm{~N}$ and $23.83 \mathrm{~N}$ (Table 2). Maximum score was recorded in $\mathrm{T}_{3}(23.83 \mathrm{~N})$ and minimum score was recorded in $\mathrm{T}_{7}(17.92$ $\mathrm{N})$. There was no significant difference observed in $\mathrm{T}_{2}[\mathrm{RWF}(78 \mathrm{~g})+\operatorname{DLP}(0 \mathrm{~g})+$ $\operatorname{DSF}(10 \mathrm{~g})], \mathrm{T}_{3}[\mathrm{RWF}(73 \mathrm{~g})+\operatorname{DLP}(5 \mathrm{~g})+$ DSF (10g)], and $\mathrm{T}_{4}[\mathrm{RWF}(70.5 \mathrm{~g})+\mathrm{DLP}$ $(7.5 \mathrm{~g})+\mathrm{DSF}(10 \mathrm{~g})]$. Gluten has been reported to be responsible for hardness of noodles (Chompreeda et al., 1987). As the level of drumstick leaf powder incorporation increased the texture of the noodles decreased. This may be due to relative reduction of gluten. 
The mean variation range in texture of cooked noodles was $0.56 \mathrm{~N}$ to $1.73 \mathrm{~N}$ (Table 2). The maximum value of texture in cooked noodles was recorded in $\mathrm{T}_{3}(1.73 \mathrm{~N})$ and minimum was recorded in $T_{2}(0.56 \mathrm{~N})$. No significant difference was observed in cooked noodles of control and $\mathrm{T}_{3}[\mathrm{RWF}(73 \mathrm{~g})+\mathrm{DLP}(5 \mathrm{~g})+\mathrm{DSF}$ $(10 \mathrm{~g})], \mathrm{T}_{4}[\mathrm{RWF}(70.5 \mathrm{~g})+\mathrm{DLP}(7.5 \mathrm{~g})+\mathrm{DSF}$ $(10 \mathrm{~g})]$ and $\mathrm{T}_{5}[\mathrm{RWF}(68 \mathrm{~g})+$ DLP $(10 \mathrm{~g})+$ DSF (10g)]. High value of hardness has been correlated positively with swelling capacity of flours/starches. Past research has indicated that flour quality and protein content affect noodle texture (Park and Baik, 2004) particularly the gluten forming proteins due to their unique visco-elastic properties (Crosbie et al., 1999).

\section{$L^{*} a^{*} b^{*}$ values}

Colour is a key quality trait (Mares and Campbell, 2001) because of the visual impact at the point of sale as it provides some indication of the quality of the product during initial and in the age of the product. Among the treatments, the $L^{*}$ value was found to be statistically significant in all the treatments except with $\mathrm{T}_{1}$ (66.99) and $\mathrm{T}_{2}$ (63.09).The maximum and minimum $L^{*}$ value was recorded in $\mathrm{T}_{1}$ (66.59) and $\mathrm{T}_{7}$ (28.67) respectively. The per cent of increase in drumstick leaf powder incorporation resulted in decreased $L^{*} a^{*}$ and $b^{*}$ values that indicates darkening of noodles compared to control (Table 3). These results are in accordance with the studies of Yadavet al., (2015) who revealed that, the apple pomace powder added noodles had significantly lower lightness than the control sample. As the level of apple pomace powder increased in the formulations $(10 \%, 15 \% \& 20 \%)$, the colour of the noodles became darker than the control, but $10 \%$ formulation was slightly less darker colour as compared to 15 per cent and 20 per cent formulations.

The maximum $a^{*}$ value was recorded in $\mathrm{T}_{1}$ (4.94) and minimum was recorded in $\mathrm{T}_{7}$ (0.94). Maximum $b^{*}$ value was recorded in $\mathrm{T}_{1}$ (27.81) and minimum was recorded in $\mathrm{T}_{7}$ (13.05) (Table 3). The visual difference, however, was relatively minor with variances of less than 6 units among $L^{*}, a^{*}$ and $b^{*}$ values. Park and Baik (2004) highlighted that instant noodles made from flour of high protein content $(>13.6 \%)$ exhibited a positive relationship in brightness (high $L^{*}$ values) but negative relationship in $b^{*}$ values.

Table.1 Treatment details

\begin{tabular}{|c|l|c|c|c|c|c|c|c|}
\hline Sl. & \multicolumn{7}{|c|}{ Ingredients } & \multicolumn{7}{c|}{ Treatments } \\
\cline { 3 - 8 } No & & $\mathbf{T}_{\mathbf{1}}$ & $\mathbf{T}_{\mathbf{2}}$ & $\mathbf{T}_{\mathbf{3}}$ & $\mathbf{T}_{\mathbf{4}}$ & $\mathbf{T}_{\mathbf{5}}$ & $\mathbf{T}_{\mathbf{6}}$ & $\mathbf{T}_{\mathbf{7}}$ \\
\hline $\mathbf{1}$ & Refined wheat flour (g) & 88.00 & 78.00 & 73.00 & 70.50 & 68.00 & 65.50 & 63.00 \\
\hline $\mathbf{2}$ & Drumstick leaf powder (g) & 0 & 0 & 5.00 & 7.50 & 10.00 & 12.50 & 15.00 \\
\hline $\mathbf{3}$ & Defatted soybean flour (g) & 0 & 10.00 & 10.00 & 10.00 & 10.00 & 10.00 & 10.00 \\
\hline $\mathbf{4}$ & Salt (g) & 1.50 & 1.50 & 1.50 & 1.50 & 1.50 & 1.50 & 1.50 \\
\hline $\mathbf{5}$ & Starch (g) & 5.00 & 5.00 & 5.00 & 5.00 & 5.00 & 5.00 & 5.00 \\
\hline $\mathbf{6}$ & Citric acid (g) & 0.10 & 0.10 & 0.10 & 0.10 & 0.10 & 0.10 & 0.10 \\
\hline $\mathbf{7}$ & Potassium carbonate (g) & 0.05 & 0.05 & 0.05 & 0.05 & 0.05 & 0.05 & 0.05 \\
\hline $\mathbf{8}$ & Sodium carbonate (g) & 0.05 & 0.05 & 0.05 & 0.05 & 0.05 & 0.05 & 0.05 \\
\hline $\mathbf{9}$ & Edible vegetable oil (Ground nut) (g) & 5.00 & 5.00 & 5.00 & 5.00 & 5.00 & 5.00 & 5.00 \\
\hline $\mathbf{1 0}$ & Guar gum (g) & 0.30 & 0.30 & 0.30 & 0.30 & 0.30 & 0.30 & 0.30 \\
\hline $\mathbf{1 1}$ & Water (ml) & 31.00 & 31.00 & 31.00 & 31.00 & 31.00 & 31.00 & 31.00 \\
\hline
\end{tabular}


Table.2 Effect of incorporation of drumstick leaf powder and defatted soybean flour on texture (raw and cooked) of instant noodles

\begin{tabular}{|c|c|c|c|}
\hline \multicolumn{2}{|r|}{ Treatments } & $\begin{array}{c}\text { Texture of } \\
\text { raw noodles }(\mathrm{N})\end{array}$ & $\begin{array}{c}\text { Texture of } \\
\text { cooked noodles }(\mathrm{N})\end{array}$ \\
\hline $\mathbf{T}_{1}$ & $\operatorname{RWF}(88 g)+D L P(0 g)+D S F(0 g)$ & 18.34 & 1.66 \\
\hline $\mathbf{T}_{2}$ & RWF $(78 g)+$ DLP $(0 g)+D S F(10 g)$ & 21.65 & 0.56 \\
\hline $\mathbf{T}_{3}$ & RWF $(73 g)+D L P(5 g)+D S F(10 g)$ & 23.83 & 1.73 \\
\hline $\mathbf{T}_{4}$ & RWF (70.5g) + DLP (7.5g)+ DSF (10g) & 23.77 & 1.47 \\
\hline $\mathbf{T}_{5}$ & RWF (68g) + DLP (10g)+ DSF (10g) & 20.47 & 1.43 \\
\hline $\mathbf{T}_{6}$ & RWF $(65.5 \mathrm{~g})+\mathrm{DLP}(12.5 \mathrm{~g})+\mathrm{DSF}(10 \mathrm{~g})$ & 18.96 & 0.74 \\
\hline $\mathbf{T}_{7}$ & RWF $(63 g)+$ DLP $(15 g)+$ DSF $(10 g)$ & 17.92 & 0.71 \\
\hline \multicolumn{2}{|c|}{ Mean } & 20.70 & 1.18 \\
\hline \multicolumn{2}{|c|}{ SEm \pm} & 0.96 & 0.16 \\
\hline \multicolumn{2}{|c|}{$\mathrm{CD}$ at $1 \%$} & 2.89 & 0.50 \\
\hline
\end{tabular}

RWF: Refined Wheat Flour, DLP: Drumstick Leaf Powder, DSF: Defatted Soybean Flour N: Newton

Common ingredients used in all the treatments
1. Salt $(1.5 \mathrm{~g})$
2. Starch $(5 \mathrm{~g})$
3. Citric acid $(0.10 \mathrm{~g})$
4. Potassium carbonate $(0.05 \mathrm{~g})$
5. Sodium carbonate $(0.05 \mathrm{~g})$
6. Edible vegetable(Groundnut) oil (5g)
7. Guar gum $(0.3 \mathrm{~g})$
8. Water $(31 \mathrm{ml})$

Table.3 Effect of incorporation of drumstick leaf powder and defatted soybean flour on Colour $\left(L^{*} a^{*} b^{*}\right)$ values of instant noodles

\begin{tabular}{|c|c|c|c|c|}
\hline \multicolumn{2}{|r|}{ Treatments } & $L^{*}$ & $a^{*}$ & $b^{*}$ \\
\hline $\mathbf{T}_{1}$ & : RWF (88g)+ DLP (0g)+ DSF (0g) & 66.59 & 4.94 & 27.91 \\
\hline $\mathbf{T}_{2}$ & : RWF (78g)+ DLP (0g)+ DSF (10g) & 63.09 & 2.43 & 22.81 \\
\hline $\mathbf{T}_{\mathbf{3}}$ & : RWF (73g)+ DLP (5g)+ DSF (10g) & 34.03 & 1.88 & 18.30 \\
\hline $\mathbf{T}_{4}$ & : RWF (70.5g) + DLP (7.5g)+ DSF (10g) & 33.81 & 1.64 & 18.15 \\
\hline $\mathbf{T}_{\mathbf{5}}$ & : RWF (68g) + DLP (10g)+ DSF (10g) & 30.05 & 1.27 & 13.32 \\
\hline $\mathbf{T}_{6}$ & $:$ RWF $(65.5 g)+$ DLP $(12.5 g)+$ DSF $(10 g)$ & 29.13 & 1.14 & 13.19 \\
\hline $\mathbf{T}_{7}$ & $:$ RWF $(63 g)+$ DLP $(15 g)+$ DSF $(10 g)$ & 28.67 & 0.94 & 13.05 \\
\hline \multicolumn{2}{|c|}{ Mean } & 40.76 & 2.03 & 18.10 \\
\hline \multicolumn{2}{|c|}{ SEm \pm} & 1.93 & 0.25 & 1.30 \\
\hline \multicolumn{2}{|c|}{$\mathrm{CD}$ at $1 \%$} & 5.77 & 0.76 & 3.88 \\
\hline
\end{tabular}

RWF: Refined Wheat Flour, DLP: Drumstick Leaf Powder, DSF: Defatted Soybean

Common ingredients used in all the treatments
1. Salt $(1.5 \mathrm{~g})$
2. Starch $(5 \mathrm{~g})$
4. Potassium carbonate $(0.05 \mathrm{~g})$
5. Sodium carbonate $(0.05 \mathrm{~g})$
3. Citric acid $(0.10 \mathrm{~g})$
7. Guar gum $(0.3 \mathrm{~g})$
8. Water $(31 \mathrm{ml})$
6. Edible vegetable(Groundnut) oil (5g) 
Table.4 Effect of incorporation of drumstick leaf powder and defatted soybean flour on sensory evaluation of instant noodles

\begin{tabular}{|c|c|c|c|c|c|c|}
\hline \multicolumn{2}{|r|}{ Treatments } & $\begin{array}{l}\text { Colour *and } \\
\text { appearance }\end{array}$ & $\begin{array}{c}\text { Flavour } \\
*\end{array}$ & Taste * & $\begin{array}{r}\text { Texture * } \\
\text { (mouth feel) }\end{array}$ & $\begin{array}{c}\text { Overall * } \\
\text { acceptability }\end{array}$ \\
\hline $\mathbf{T}_{1}$ & : RWF $(88 g)+D L P(0 g)+D S F(0 g)$ & 7.95 & 7.78 & 7.51 & 7.58 & 7.70 \\
\hline $\mathbf{T}_{2}$ & : RWF $(78 g)+$ DLP $(0 g)+$ DSF $(10 g)$ & 6.56 & 6.24 & 6.44 & 6.67 & 7.08 \\
\hline $\mathbf{T}_{3}$ & : RWF $(73 g)+$ DLP $(5 g)+D S F(10 g)$ & 8.66 & 8.25 & 8.11 & 8.28 & 8.21 \\
\hline $\mathbf{T}_{4}$ & $:$ RWF $(70.5 \mathrm{~g})+\mathrm{DLP}(7.5 \mathrm{~g})+\mathrm{DSF}(10 \mathrm{~g})$ & 8.24 & 7.10 & 7.58 & 7.58 & 7.46 \\
\hline $\mathbf{T}_{5}$ & : RWF (68g) + DLP (10g)+ DSF (10g) & 7.50 & 6.90 & 7.25 & 7.60 & 7.24 \\
\hline$T_{6}$ & : RWF $(65.5 \mathrm{~g})+$ DLP $(12.5 \mathrm{~g})+\mathrm{DSF}(10 \mathrm{~g})$ & 6.58 & 6.66 & 6.75 & 6.61 & 6.53 \\
\hline $\mathbf{T}_{7}$ & : RWF (63g) + DLP (15g)+ DSF (10g) & 6.26 & 6.11 & 6.18 & 6.41 & 6.08 \\
\hline \multicolumn{2}{|c|}{ Mean } & 7.39 & 7.00 & 7.11 & 7.25 & 7.18 \\
\hline \multicolumn{2}{|c|}{ SEm \pm} & 0.61 & 0.51 & 0.43 & 0.38 & 0.46 \\
\hline \multicolumn{2}{|c|}{$\mathrm{CD}$ at $1 \%$} & 1.83 & 1.52 & 1.30 & 1.15 & 1.36 \\
\hline
\end{tabular}

RWF: Refined Wheat Flour, DLP: Drumstick Leaf Powder, DSF: Defatted Soybean

* Out of 9 points

Common ingredients used in all the treatments
1. Salt $(1.5 \mathrm{~g})$
2. Starch $(5 \mathrm{~g})$
5. Sodium carbonate $(0.05 \mathrm{~g})$
3. Citric acid $(0.10 \mathrm{~g})$
4. Potassium carbonate $(0.05 \mathrm{~g})$
8. Water $(31 \mathrm{ml})$
6. Edible vegetable(Groundnut) oil (5g)
7. Guar gum $(0.3 \mathrm{~g})$

Fig.1 Flow chart for preparation of instant noodles incorporated with drumstick leaf powder and defatted soybean flour

Refined wheat flour, drumstick leaf powder, defatted soybean flour, salt, starch, citric acid, potassium carbonate, sodium carbonate, vegetable oil and gum

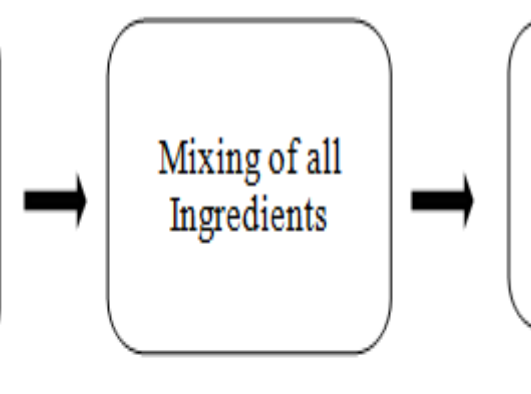

Dough formation using water and passed through roller

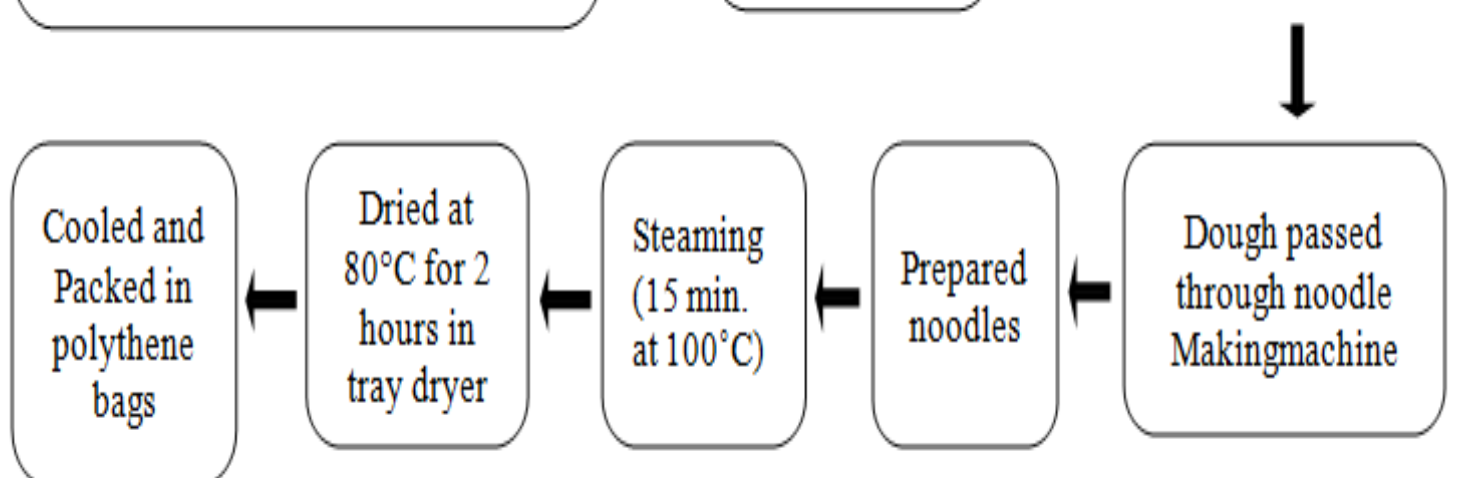


Fig.2 Noodles prepared from drumstick leaf powder and other ingredients at different levels

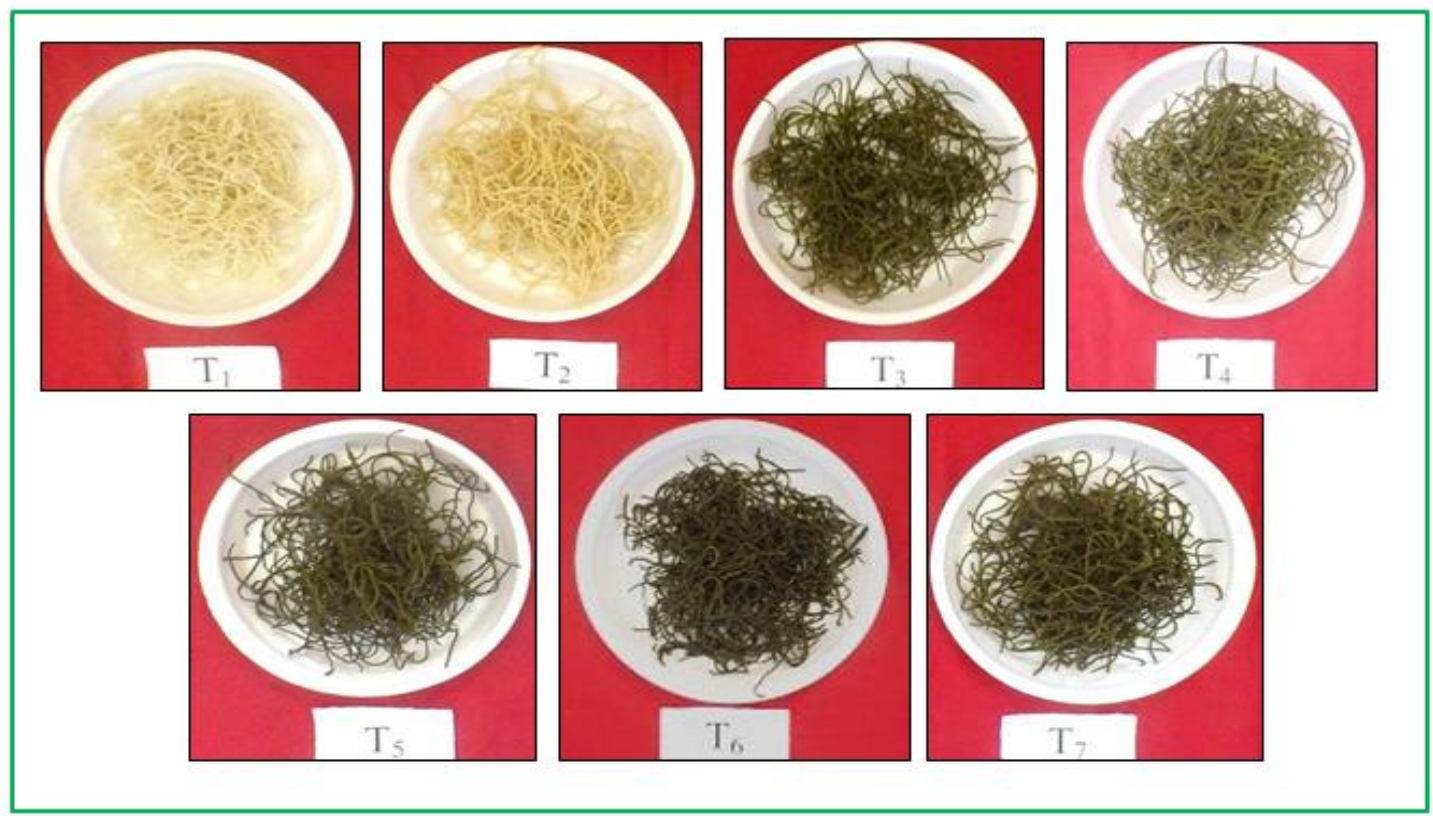

Factors controlling colour stability, which include alkaline formulation, flour refinement and enzymatic browning associated with poly phenoloxidase, have been extensively investigated (Hatcher et al., 2008). Ramu et al., (2016) found that with the increase in spinach paste, there was a significant decrease $(\mathrm{p} \leq 0.05)$ in brightness $(L)$ value from 82.45 to 44.35 and also there was an increase in redness $(a)$ in instant noodles from 0.73 to 25.68. Yellowness $(b)$ in instant noodles significantly $(\mathrm{p} \leq 0.05)$ increased from 13.37 to 61.48 .

\section{Sensory evaluation}

Colour and appearance are the most important assessment attributes for noodle quality (Bhattacharya, Luo. and Corke (1999); Miskelly (1984). Colour is one of the major response variables governing food acceptance. Since colour relies on the sense of sight, the colour of the noodles was one of the outstanding parameters in the decision of the panelist. In the present study significant differences were observed in colour and appearance of noodles in different treatments. Maximum score for colour was recorded in $\mathrm{T}_{3}$ (8.66) and minimum in $\mathrm{T}_{7}$ (6.26). Among the treatments, $\mathrm{T}_{3}(5 \%$ drumstick leaf powder incorporated noodles) had good colour and appearance scores, it might be due to the fact that incorporation of drumstick leaf powder at lower levels gives attractive light green colour which was well accepted by the consumers (Table 4). Omeire et al., (2015) revealed that the average sensory scores for colour of the prepared cassava noodles ranged from 5.25 to 8.70. The results of the study is similar to the findings of Taneya et al., (2014) who reported that the instant noodles containing 30 per cent sweet potato flour secured the highest score (7.7) for colour and the noodles containing only wheat flour gave lowest score (6.9).

Significantly maximum score for flavor was recorded in $\mathrm{T}_{3}$ (8.25) and the minimum mean score was recorded in $\mathrm{T}_{7}(6.11)$. Lowest score of flavour in $\mathrm{T}_{7}$ might be due to typical drumstick leaf powder flavour and astringency after cooking. Flavour of noodles was accepted by incorporation of drumstick 
leaf powder and defatted soybean flour up to 10 per cent but beyond 10 per cent significantly reduced the flavour scores.

The maximum taste was recorded in $\mathrm{T}_{3}(8.11)$ followed by $\mathrm{T}_{4}$ (7.58) and minimum taste score was recorded in $\mathrm{T}_{7}$ (6.18). The data in Table 4 shows that the taste score decreased with the increase in incorporation of drumstick leaf powder. Least scores in $\mathrm{T}_{7}$ might be due to typical flavour and astringency of drumstick leaf powder which adds bitterness after taste. No significant difference was observed between the taste scores of control $\left(\mathrm{T}_{1}\right), 10$ per centdefatted soybean flour incorporated noodles $\left(\mathrm{T}_{2}\right)$ and 10 per cent defatted soybean flour +10 per cent drumstick leaf powder $\left(\mathrm{T}_{5}\right)$ incorporated noodles. So from these results one can conclude that noodles incorporated with 10 per cent drumstick leaf powder were acceptance for taste. These results are in accordance with study of Wani et al., (2013) who reported that the addition of cauliflower leaves to noodles up to $10 \%$ was found acceptable.

The maximum and minimum mean texture score was recorded in $\mathrm{T}_{3}$ (8.28) and $\mathrm{T}_{7}(6.41)$ respectively. The texture scores of the nutridensed noodles was found to be good in $\mathrm{T}_{3}$ (5\% drumstick leaf powder $+10 \%$ defatted soybean incorporated) treatment compared with other treatments (Table 4). Omeire et al., (2015) reported that the average sensory score for texture of the prepared cassava noodles ranged between 6.75 and 8.25. Taneya et al., (2014) revealed that the range of instant noodles score for texture was 6.5-8.0. The lowest score (6.5) was secured by noodle containing wheat flour and the highest score (8.0) for texture was in instant noodles containing 30 per cent sweet potato flour.

A perusal of data in Table 4 showed significantly maximum score for overall acceptability in $\mathrm{T}_{3}[\mathrm{RWF}(73 \mathrm{~g})+\operatorname{DLP}(5 \mathrm{~g})+$ DSF (10g):8.21] and minimum mean score was recorded in $\mathrm{T}_{7}$ [RWF $(63 \mathrm{~g})+\mathrm{DLP}(15 \mathrm{~g})$ + DSF (10g): 6.08]. The maximum score in $\mathrm{T}_{3}$ may be due to low percent of drumstick leaf powder incorporation, which did not affect the quality in terms of colour and appearance, flavour, texture and taste through sensory evaluation. However, there was no significant difference observed between $\mathrm{T}_{5}$ [RWF (68g) + DLP (10g) + DSF (10g)] and control [RWF (88g) + DLP (0g) + DSF (0g)]. Wani et al., (2013) reported that the addition of cauliflower leaves to noodles up to 10 per cent was found to be highest score for overall acceptability.

Instant noodles prepared by incorporated with drumstick leaf powder and defatted soybean flour shows the significant difference in texture, colour and organoleptic evaluation. The best results observed among the drumstick leaf powder added treatments, treatment $\mathrm{T}_{3}(73 \%$ Refined wheat flour $+5 \%$ Drumstick leaf powder and 10\% Defatted soybean flour) was found better quality and acceptance when compared to other treatments.

\section{Acknowledgment}

University of Horticultural Sciences Bagalkot facilitates all the difficulties that suffered this research. Therefore, my Deepest thanks to University of Horticultural Sciences Bagalkot for the finance, cooperation and encouragement.

\section{References}

Bhattacharya, M., Zee, S, Y. and Corke, H., 1999. Physicochemical properties related to quality of rice noodles. Cereal Chem., 76(6), 861-867.

Chompreeda, P., Resurreccion, A.V.A., Hung, Y.C. and Beuchat, L.R., 1987. Quality 
evaluation of peanut-supplemented Chinese type noodles. J Food Sci., 52, 1740-1741.

Collins, J.L., and Pangloli, P., 1997. Chemical, physical and sensory attributes of noodles with added sweet potato and soy flour. Journal of Food Science. 62, 622-625.

Crosbie, G.B., Ross, A.S., Moro, T. and Chiu, P.C., 1999.Starch and protein quality requirements of Japanese alkaline noodles (Ramen).Cereal Chem., 76(3), 328-334.

Gernah, G.I., Ariahu, G.C. and Ingbian, E.K., 2011.Effect of malting and lactic fermentation on some chemical and functional properties of maize. American J Food Techno., 16, 404-412.

Hatcher, D.W., Edwards, N.M. and Dexter, J.E., 2008. Effects of particle size and starch damage of flour and alkaline reagent on yellow alkaline noodle characteristics. Cereal Chem., 85, and 425-32.

Hu, R.B., Qian, J.C., Deng, Z.Y. and Zhang, Z.X., 2006. The factors influencing on the colorof Chinese white salted noodles. ActaAgron Sin., 3(9), 13381343.

Isitua, C.C., Lozano, M.J.S.M., Jaramillo, C.J. and Dutan, F., 2015. Phytochemical and nutritional properties of dried leaf powder of Moringa oleiferalam. From machala el oro province of ecuador. Asian J. Plant Sci. Res., 5(2), 8-16.

Janto, M., Pipatsattayanuwong, S., Kruk, M.W., Hou, G. and McDaniel, M.R., 1998.Developing noodles from US wheat varieties for the Far East market: sensory perspective. Food Qual Prefer., 9, 403-412.

Mares, D.J., and Campbell, A.W., 2001. Mapping components of flour and noodle colour in Australian wheat. Australian J Agri Res., 52(12), 12971309.
Menkov, N.D., Durakova, A.G. and Krasteva, A., 2005, Moisture sorption isotherms of common bean flour at several temperatures. Electronic Journal of Environmental. Agric Food Chem., 4(2), 892-898.

Miskelly, D.M., 1984. Flour components affecting paste and noodle colour. $J$ Sci Food Agri., 35(4), 463-471.

Omeire, G.C., Nwosu, J.N., Kabuo, N.O. and Nwosu, M.O., 2015. Cooking properties and sensory evaluation of enriched cassava or wheat noodles. Int J Innov Res Sci Engtechnol., 3(2), 46-50.

Park, C.S., and Baik, B.K., 2004.Significance of amylose content of wheat starch on processing and textural properties of instant noodles. Cereal Chem., 81(4), 521-526.

Ramu, L., JyotikiranMaloo, S. and Ramugolla, 2016. Physical, chemical and sensory properties of spinach paste fortified instant noodles. Int J Innov. Technol Res., 4(6), 5318-5322.

Senthil, A., Ravi, R., Bhat, K.K. and Seethalakshmi, M.K., 2002.Studies on the quality of fried snacks based on blends of wheat flour and soya flour.Food Quality and Preference 13, 267-273.

Skrbic, B., Milovac, S., Dodig, D. and Filipcev, B., 2009. Effects of hull-less barley flour and flaked on bread nutritional composition and sensory properties. Food Chemistry.115, 982988.

Taneya, M.L.J., Biswas, M.M.H. and Din, M.S.U., 2014. The studies on the preparation of instant noodles from wheat flour supplementing with sweet potato flour. J Bangladesh Agril Univ., 12(1), 135-142.

Vetter, J.L., 1988.Commercially available fibre ingredients and bulking agents. American Institute of Baking Technical Bulletin. 10(5), 1-6. 
Wang, J., Rosell, C.M. and Benedito de Barber, C., 2002. Effect of the addition of different fibres on wheat dough performance and bread quality. Food Chemistry. 79, 221-226.

Wani, T.A., Sood, M., Amin, Q.A., Wani, N. and Kour, H., 2013.Nutritional and organoleptic evaluation of noodles prepared by supplementation with cauliflower leaves. Asian J Hort., 8(1), 304-312.

Yadav, S., and Gupta, R.K., 2015.Formulation of noodles using apple pomace and evaluation of its phytochemicals and antioxidant activity. J Pharmacogn Phyto chem., 4(1), 99106.

\section{How to cite this article:}

Vittal Kamble, G. Bhuvaneshwari, Vasant M. Ganiger, Deepa Terdal and Kotikal, Y.K. 2018. Effect of Incorporation of Drumstick Leaf Powder and Defatted Soybean Flour on Texture, Colour and Organoleptic Evaluation of Instant Noodles. Int.J.Curr.Microbiol.App.Sci. 7(02): 3632-3641. doi: https://doi.org/10.20546/ijcmas.2018.702.432 